\title{
SUMBER NORMA-NORMA HUKUM EKONOMI ISLAM
}

\author{
Amirzan \\ Amirzan1799@Gmail.com \\ Afiliasi (Universitas Muhammadiyah Makassar)
}

\section{A. HAKIKAT HUKUM EKONOMI}

Ekonomi dalam banyak literature, ekonomi berasal dari bahasa Yunani, yaitu kata "oikos atau oiku" dan "nomos" yang berarti peraturan rumah tangga. Dengan kata lain, ekonomi adalah semua yang bersangkutan atau berhubungan langsung dengan perikehidupan dalam rumah tangga.Dalam artian rumah tangga di sini bukan hanya kebutuhan langsung terhadap yang ada di dalam rumah tangga seperti, suami, istri atau anak. Akan tetapi juga rumah tangga dalam arti luas seperti, rumah tangga bangsa, Negara dan dunia.

Hukum ekonomi adalah pernyataan mengenai kecenderungan suatu hubungan sebab akibat antara dua kelompok fenomena. Semua hukum ilmiah adalah hukum dalam arti yang sama. Selain itu hukum ekonomi dapat berarti suatu hubungan sebab akibat atau pertalian peristiwa ekonomi yang saling berhubungan satu dengan yang lain dalam kehidupan ekonomi sehari-hari dalam masyarakat. Akan tetapi, hukum-hukum ilmu ekonomi tidak bisa setepat dan seakurat seperti dalam hukum ilmu-ilmu pengetahuan alam (eksak). Hal ini disebabkan oleh alasan-alasan berikut. Pertama, ilmu ekonomi adalah ilmu pengetahuan sosial, dengan demikian harus mengendalikan banyak orang yang dikendalikan oleh banyak motif. Unsur ini dalam situasinya menyebabkan kenyataan bahwa hukum-hukum ekonomi hanya dapat memberikan hasil ratarata. Kedua, data ekonomi tidak saja banyak jumlahnya, tetapi data itu sendiri bisa berubah. Oleh karena sikap, selera, dan watak manusia berubah pada suatu jangka waktu, maka tugas untuk meramalkan, bagaimanakah perbedaan reaksi manusia terhadap suatu perubahan keadaan tertentu pada kesempatan yang berbeda, menjadi sangat riskan dan berbahaya. Ketiga, banyak faktor yang tidak dapat diketahui dalam situasi tertentu. Semua data tidak dapat diketahui dan ramalan berdasarkan data yang diketahui yang ada kemungkinan untuk direkayasa oleh pengaruh data yang tidak diketahui.

\section{B. AL-QUR'AN}

Al-Qur'an memuat wahyu Allah SWT, Pencipta alam semesta, yang ditujukan kepada ummat manusia. Ini merupakan message dari Allah kepada manusia. Karena itu, al-Qur'an menjadi sangat urgen bagi kita. Untuk berpegang teguh pada message tersebut, yang dibutuhkan pertama kali tentu memahami kandungannya. Untuk tujuan itulah, maka kandungan al-Qur'an tersebut harus dipelajari dengan mendalam. Kenyataannya, banyak orang telah menghabiskan banyak hidupnya untuk mengkaji al-Qur'an; membaca dan merefleksikannya dalam rangka membangun aspek fisik dan spirit mereka. 
Mereka juga telah menemukan makna dan implikasi baru untuk kepentingan mereka sendiri.

Yang kedua, beberapa pengetahun yang secara spesifik mengenai pembahasan tersebut, yang berkaitan dengan message tadi adalah juga dibutuhkan untuk secara penuh memahami makna dan implikasinya. Meski, beberapa bagian dari pengetahuan spesifik ini bisa diambil dari al-Qur'an itu sendiri, namun bagian lain dari pengetahuan tersebut hanya bisa ditemukan melalui kajian dan Research yang mendalam.

\section{HADIS DAN SUNAH}

Sunnah bisa berarti perilaku (sirah), jalan (thariqah), kebiasaan atau ketentuan. Sunnah dalam pengertian ini bisa mencakup sunnah yang baik (sunnah hasanah) maupun sunnah yang buruk (sunnah qabihah). Dalam pengertian ini Al-Qur'an menyebutnya dengan Sunnah al-Awwaliin, yakni sunnah yang telah diturunkan oleh Allah SWT kepada orang-orang terdahulu (Al-Anfal:38). Istilah Sunnah juga terdapat dalam teks hadits, yang mencakup pengertian sunnah yang baik dan sunnah yang buruk, sebagaimana hadits riwayat Muslim yang Mengatakan:

"Barangsiapa di dalam Islam memperkenalkan perilaku atau kebiasaan baik (sunnah hasanah), ia akan memperoleh pahala atas perilaku tersebut dan pahala orang-orang yang ikut melakukannya di kemudian hari. Sebaliknya siapa yang memperkenalkan perilaku yang buruk (sunnah sayyi'ah), ia akan memperoleh dosa perilaku tersebut dan dosa orang-orang yang melakukannya di kemudian hari tanpa ada sesuatu yang mengurangi dosa mereka".

Menurut Fazrur Rahman, perilaku generasi setelah Nabi adalah personifikasi dari perilaku Rasulullah SAW yang dihidupkan secara turuntemurun. As-sunnah sebagai tradisi yang hidup, yang bermula dari perilaku Muhammad SAW, diikuti para sahabatnya, diikuti oleh pengikut sahabat, demikian seterusnya sehingga perilaku itu menjadi melembaga dan mendarah daging. Apabila proses internalisasi telah terjadi, institusionalisasi perilaku akan membuahkan kesepakatan sosio-kultural. Secara sosiologis, adanya kesesuaian antara sistem nilai, sistem sosial dan sistem budaya sehingga membentuk kolektifitas tingkah laku. Sedangkan menurut Hasbi Ash-Shidieqie, sunnah adalah pengejawantahan perilaku menurut contoh Rasulullah SAW yang merujuk pada hadits. (perbuatan yang terus menerus dilakukan sehingga menjadi semacam tradisi )

\section{IJMA}

Ijma' menurut bahasa (lughah) Ialah mengumpulkan perkara dan memberi hukum atasnya serta menyakininya. Sedangkan Ijma' menurut istilah ialah kebulatan pendapat memua ahli ijtihad sesudah wafatnya Rasulullah SAW pada suatu masa atas sesuatu hukum syara'.10 Pada masa para sahabat Nabi, 
Abu bakar dan Umar di dalam menjalankan Ijma' terkesan bahwa Ijma' ketika itu adalah hasil permusyawaratan yang dilakukan oleh mereka dan yang dipandang dapat mewakili rakyat atas dasar perintah Kepala Negara. Akan tetapi, para Mujtahid disaat para khulafa' tidak mementingkan lagi dasar Permusyawaratan namun lebih mengartikan Ijma' dengan persetujuan faham para ahli ijtihad atau para fuqaha' terhadap suatu perkara. Menurut Romli dalam bukunya Muqaranah Mazahib Fil Ushul mengungkapkan bahwa Ijma' dapat berarti sepakat atau konsensus dari sejumlah orang terhadap sesuatu perkara.

Adapun menurut para ahli Ushul Fiqh, pengertian Ijma' dapat dikemukakan sebagai berikut:

1. Imam Al-Ghazali yang menyatakan dalam kitab al-Mustasfa bahwa Ijma' merupakan suatu kesepakatan umat Nabi Muhammad Saw atas satu perkara yang berhubungan dengan urusan agama

2. Imam al-Subki dalam kitabnya Matn Jami'al-Jawawi, mengungkapkan bahwa Ijma' ialah suatu kesepakatan para mujtahid setelah wafatnya Nabi Muhammad saw terhadap persoalan yang berkaitan dengan hukum syara'.

\section{E. IJTIHAD DAN QIYAS}

Sumber hukum yang paling mendasar pada tahap permulaan dalam Islam adalah al-Qur'an, yang dirinci, diberi contoh, dan ditafsirkan oleh Sunnah Nabi. Oleh karena itu, al-Qur'an dan al-Sunnah Memiliki kedudukan sebagai sumber syariat dalam Islam. Pada masa Nabi, segala permasalahan yang berhubungan dengan Islam dapat ditanyakan langsung kepada beliau, Nabi Muhammad saw kemudian menjelaskannya dalam bentuk ucapan, perbuatan, atau pernyataannya dengan tanpa memerlukan penggunaan kaidah-kaidah atau metode-metode yang sistematis dan terukur secara akademis. Setelah Nabi wafat maka kewajiban untuk menerangkan hukum-hukum Allah dilakukan oleh para sahabat. Sejak saat itu para sahabat mengambil alih peran Nabi dengan berusaha untuk menggali dan menafsirkan ayat-ayat al-Qur'an dan hadits-hadits Nabi dalam menjawab berbagai persoalan yang timbul.

Proses ijtihad pada masa awal memiliki hubungan yang erat dengan alQur'an. Dinyatakan demikian karena para sahabat yang juga sebagai mujtahid ketika dihadapkan pada permasalahan-permasalahan hukum yang baru berupaya dengan sungguh-sungguh dalam menggali makna-makna dasar ayatayat Al-Qur'an hingga mengeluarkan kandungan hukumnya. Meski demikian, ijtihad dalam perkembangan selanjutnya berbeda dengan tafsir. Tafsir menurut al-Zarkasyi dalam al-Burhân adalah menerangkan makna-makna al-Qur'an, mengeluarkan hukum-hukumnya, dan hikmah-hikmahnya.Menurut Abu Hayyan, tafsir membahas tentang cara pengucapan lafazh al-Qur'an, petunjuk petunjuknya, hukum-hukumnya baik ketika berdiri sendiri maupun ketika tersusun, dan makna yang dimungkinkan baginya ketika tersusun dengan halhal lain yang melengkapinya. Meskipun antara ijtihad dan tafsir secara definisi 
memiliki unsur persamaan, namun dilihat dari sudut pandang ilmu-ilmu keislaman istilah keduanya dibedakan.

Dalam hukum Islam, qiyas adalah sebuah solusi yang ditawarkan untuk berbagai kasus hukum yang tidak disebutkan secara eksplisit dalil dalam sumber hukum Islam. Diketahui bahwa Imam Syafi'i adalah penggagas konsep qiyas. Dalam pandangannya, berbagai kasus hukum yang terdapat dalam masyarakat Muslim yang tidak jelas diatur dalam al-Qur'an atau Sunnah dapat diselesaikan melalui qiyas, baik dalam bentuk qiyas jaly atau qiyas khafi. Semua orang mengetahui bahwa hukum Islam terkandung dalam Al-Quran, tradisi kenabian, pendapat dari generasi awal ulama, konsensus dan kontroversi di antara mereka, memiliki kapasitas intelektual yang tinggi dan analisis yang tajam di mana ia dapat mengidentifikasi fakta yang tidak jelas, dan bisa menjadi al-Qais. Konsep qiyas terdiri dari empat elemen al-ashl yaitu hukum asli yang berasal dari teks, al-far, atau dari sebuah al-'illah. Sebuah qiyas tidak boleh melampaui teks dari sumber utama hukum Islam, karena diambil dari teks yang ada. 


\section{DAFTAR PUSTAKA}

Aziz, A. (2011). DASAR-DASAR EKONOMI ISLAM.

Al Arif, M. N. R. (2012). Wakaf uang dan pengaruhnya terhadap program pengentasan kemiskinan di Indonesia. Jurnal Indo-Islamika, 2(1), 17-29.

RIFAAH, H. (2019). PENAFSIRAN SABAR DALAM TAFSIR FAID ALRAHMA $><$ N FI $<$ TARJAMAH KALA $<$ M MALIK AL-DAYYA $<$ N KARYA MUHAMMAD SHA $>$ LIH BIN UMAR AL-SAMARANI.

Hairillah, H. (2015). Kedudukan As-sunnah Dan Tantangannya Dalam Hal Aktualisasi Hukum Islam. Mazahib, 14(2).

Asrowi, A. (2018). Ijma dan Qiyas dalam Hukum Islam. Aksioma Al-Musaqoh: Journal of Islamic Economics and Business Studies, 1(1).

Safe'i, A. (2017). REDEFINISI IJTIHAD DAN TAQLID: Upaya Reaktualisasi dan Revitalisasi Perspektif Sosio-Historis. ADLIYA: Jurnal Hukum dan Kemanusiaan, 11(1), 25-40.

Azhari, F. (2014). Qiyas Sebuah Metode Penggalian Hukum Islam. Syariah: Jurnal Hukum Dan Pemikiran, 13(1). 